\title{
Koping Stres dan Stres pada Perawat di Rumah Sakit Jiwa "X"
}

\author{
Yulia Dyah Ayu Permatasari \\ Muhana Sofiati Utami \\ Program Studi Psikologi, Fakultas Psikologi Universitas Gadjah Mada, Yogyakarta
}

\begin{abstract}
The purpose of this study was to examine the correlation between the dimensions of coping stress and stress among nurses who work on psychiatric units. The hypothesis stated in this study is that there is a correlation between the dimensions of coping stress and stress among nurses who work on psychiatric units at psychiatric hospital " $\mathrm{X}$ ". This study used two scale, coping stress scale and stress scale. Subject of this study are psychiatryc units nurses who work in psychiatric hospital " $\mathrm{X}$ ". The data from this study was analyzed using correlation product moment technique from Pearson. The result showed that there is no significant correlation between the dimensions of coping stress and stress among nurses who work on pyshiatric room. The analysis result between problem focused coping dimension and stress showed that $r=0.091 ; p$ $=0.210(p>0.05)$. Meanwhile, the analysis result between emotional focused coping and stress showed that $\mathrm{r}=-0.042 ; \mathrm{p}=0.709$ ( $\mathrm{p}>0.05$ ). Therefore, the result of this research suggest that there is no significant correlations between the dimensions of coping stress and stress among nurses who work on pyshiatric room.
\end{abstract}

Keywords : coping stress, nurses, stress

\begin{abstract}
Abstrak. Tujuan penelitian ini adalah untuk menguji korelasi antara dimensi-dimensi koping stres dan stres pada perawat yang bekerja pada bagian rawat inap psikiatri. Hipotesis penelitian ini adalah terdapat korelasi antara dimensi-dimensi koping stres dan stres pada perawat yang bekerja pada bagian rawat inap psikiatri rumah sakit jiwa " $X$ ". Penelitian ini menggunakan dua skala, yaitu skala koping stres dan stres. Responden dalam penelitian ini adalah perawat yang bekerja di rumah sakit jiwa "X". Data dari penelitian ini dianalisis menggunakan teknik korelasi Product Moment oleh Pearson. Hasil penelitian ini menunjukkan bahwa tidak terdapat korelasi yang signifikan antara dimensi-dimensi koping stres dan stres pada perawat yang bekerja pada bagian rawat inap psikiatri. Hasil analisis antara dimensi problem focus coping dan stres menunjukkan $r=0,091 ; p=0,210(p>0,05)$. Sementara itu, hasil analisis antara dimensi emotional focused coping dan stres menunjukkan $r=-0,042 ; p=0,709(p>0,05)$. Oleh karena itu, hasil penelitian ini menunjukkan bahwa tidak terdapat korelasi yang signifikan antara dimensidimensi koping stres dan stres pada perawat yang bekerja pada bagian rawat inap psikiatri.
\end{abstract}

Kata Kunci: koping stres, perawat, stres

Korespondensi: Yulia Dyah Ayu Permata Sari. E-mail: yuliadyahayu@gmail.com 
Perawat merupakan mayoritas profesional kesehatan yang bekerja di rumah sakit dengan tuntutan kerja tinggi (Maria, Pavlos, Eleni, \& Thamme, 2010). Perawat merupakan bagian yang tidak terpisahkan dari keseluruhan proses pemulihan pasien, tidak hanya sekedar melakukan rutinitas seperti memeriksa tekanan darah, denyut nadi, atau suhu pasien saja. Menurut The American Medical Association Encyclopedia of Medicine bahwa perhatian perawat lebih tertuju pada reaksi keseluruhan pasien terhadap penyakitnya daripada penyakit itu sendiri. Perawat lebih memusatkan perhatiannya untuk mengatasi rasa sakit fisik pasien, melepaskan pasien dari penderitaan mental dan jika mungkin menghindari timbulnya komplikasi. Selain itu, perawat juga memberikan perhatian dengan penuh pengertian yang mencakup mendengarkan dengan sabar semua kekhawatiran dan ketakutan pasien serta memberikan dorongan emosi dan penghiburan (Wijono, 2006).

Di rumah sakit jiwa, pelayanan keperawatan dilakukan oleh perawat kesehatan jiwa. Perawat kesehatan jiwa adalah bagian dari perawat umum, tetapi khusus menangani pasien gangguan jiwa dan bekerja di rumah sakit jiwa. Namun demikian ada sedikit perbedaan antara perawat umum dengan perawat kesehatan jiwa. Perawat umum lebih menitikberatkan pada keadaan jasmaniah pasien meskipun keadaan mentalnya tidak terasa, sedang perawat kesehatan jiwa lebih menitikberatkan pada kesehatan mental pasien tanpa mengesampingkan keadaan jasmaniahnya. Selain itu, kondisi mental pasien yang labil mengharuskan perawat untuk bersikap sabar dalam melakukan berbagai macam peranan untuk mengetahui berbagai macam kebutuhan pasien. Perilaku pasien gangguan jiwa yang sulit diprediksi dan berbahaya juga menuntut perawat untuk lebih berhati-hati dan waspada dalam memberikan perawatan.

Kesiapan baik fisik maupun psikologis mutlak diperlukan perawat dalam menjalankan tugasnya. Seringkali perawat menghadapi situasi yang tidak menyenangkan (risk situation) di tempat kerjanya dengan perilaku pasien yang mampu membuat perawat kehilangan konsentrasi. Perilaku kekerasan yang dilakukan pasien dapat berakibat fatal baik bagi perawat maupun pasien. Bila situasi yang menekan ini tidak segera diatasi, tidak menutup kemungkinan akan menimbulkan stres dan konflik pada diri perawat. Berbagai cara yang dilakukan oleh perawat untuk mengatasi agresivitas pasien yang diarahkan padanya akan menimbulkan berbagai dampak negatif baik pada diri perawat sendiri maupun pasien (As'ad \& Soetjipto, 2000).

Penelitian yang dilakukan The National Institute Occupational Safety and Health (2012) menunjukkan bahwa pekerjaan-pekerjaan yang berhubungan 
dengan rumah sakit atau kesehatan memiliki kecenderungan tinggi untuk terkena stres atau depresi. Salah satu dari pekerjaanpekerjaan tersebut adalah perawat (Selye dalam Prihatini, 2007). Pada penelitian yang dilakukan bersama perawat-perawat yang bekerja di rumah sakit jiwa, Humpel dan Caputi (2001) melacak enam kategori stresor pada perawat jiwa, yaitu karakteristik pasien yang negatif, masalah pengorganisasian administrasi, keterbatasan sumber daya, penampilan staf, konflik staf dan masalah penjadwalan. Para perawat juga berpendapat bahwa pasien rumah sakit jiwa tidak akan tahu ketika dia dibentak atau dimarahi, jadi menurut perawat membentak pasien itu adalah suatu hal yang biasa dilakukan.

Berdasarkan data yang diperoleh dari penelitian yang dilakukan oleh Elita, Setiawan, Wahyuni, dan Woferst (2011) di RSJ Tampan Provinsi Riau, perawat menyatakan sering mengalami perilaku kekerasan baik berupa kekerasan verbal maupun serangan secara fisik dari pasien. Sehingga terkadang perawat merasa cemas terutama bila bertugas di malam hari. Namun para perawat tetap mampu melaksanakan tugasnya dengan baik, karena menurut perawat tindakan yang diperoleh dari pasien jiwa adalah risiko pekerjaan yang harus diambil dan diterima dengan sebaik-baiknya.

Pada penelitian yang dilakukan Azhar (2010) tentang gambaran stres perawat di rumah sakit jiwa, dari 54 perawat yang diberikan kuesioner tentang pengukuran tingkat stres, didapati 13 perawat mengalami stres. Penelitian yang dilakukan Kusumawati (2008) tentang stres perawat di instalasi rawat inap RSJD Dr. Amino Gondohutomo Semarang didapati bahwa gejala yang timbul pada stres perawat saat melakukan penanganan pasien dengan perilaku kekerasan yang dijumpai di rumah sakit jiwa meliputi sedih, menghindar, emosi, marah, kelelahan, lebih waspada, intonasi suara jadi tinggi, berpikir tidak realistis, dan khawatir.

Penelitian terkait stres pada perawat di rumah sakit jiwa telah diteliti oleh penelitipeneliti sebelumnya. Riset oleh Mangoulia, Koukia, Fildissis, dan Katostaras (2015) di Yunani pada 174 perawat rumah sakit jiwa yang tergabung pada 12 rumah sakit swasta, menyatakan kategori tinggi pada stres traumatik. Hasil studi oleh Wang, dkk. (2015) pada 154 perawat di Taiwan disebutkan bahwa keadaan stres perawat berkaitan positif dengan tingkat depresi, namun stres berkaitan negatif dengan resourcefulness (ketrampilan menbantu diri sendiri dan mencari bantuan dari orang lain). Penelitian oleh Hasan (2017) menyatakan bahwa kondisi yang paling menyebabkan perawat rumah sakit jiwa mengalami stres ialah penganiayaan fisik dari pasien, berurusan dengan pasien yang berpotensi bunuh diri, peristiwa yang tidak 
terduga, permintaan yang terlalu banyak dari pasien, serta iklim kerja dengan kolega.

Lazarus dan Folkman (1984) juga mendefinisikan stres sebagai segala peristiwa/kejadian baik berupa tuntutantuntutan lingkungan maupun tuntutantuntutan internal (fisiologis/psikologis) yang menuntut, membebani, atau melebihi kapasitas sumber daya adaptif individu. Stres dapat juga didefinisikan sebagai keseluruhan proses yang meliputi stimulasi, kejadian, peristiwa dan respon, interpretasi individu yang menyebabkan timbulnya ketegangan di luar kemampuan individu untuk mengatasinya (Rice, 1992). Stres yang berkepanjangan dapat berdampak pada aspek dan sistem tubuh seseorang. Stres berdampak pada emosional, fisiologis, kognitif, dan perilaku. Dampak secara emosional meliputi cemas, depresi, tekanan fisik, dan psikologis. Dampak kognitif berakibat pada penurunan konsentrasi, peningkatan distraksi, dan berkurangnya kapasitas memori jangka pendek. Dampak terhadap psikologis berakibat pada pelepasan epinefrin, norepinefrin, pennonaktifan sistem pencernaan, nafas cepat, peningkatan denyut jantung, dan kontraksi pembuluh darah. Dampak pada perilaku misalnya meningkatnya ketidakhadiran kerja, mengganggu pola tidur, dan mengurangi kualitas pekerjaan (Eysenck, 1993).

Secara umum, Visides, Eddy, dan Mozie (dalam Rice, 1992) mengatakan bahwa terdapat empat aspek dalam melihat gejala-gejala stres meliputi aspek fisik, emosi, kognitif, dan perilaku. Aspek fisik, seperti kelelahan, gangguan fisik, serta kerentanan terhadap penyakit. Aspek emosi, yang dapat ditunjukkan dengan labilitas perasaan (marah, sedih, tersinggung, dll), kecemasan, maupun penurunan minat terhadap aktivitas. Aspek kognitif, yang ditunjukkan dengan adanya persepsi negatif terhadap peran yang dijalaninya ataupun persepsi negatif terhadap kemampuan untuk menghadapi tekanan yang muncul dalam menjalankan perannya. Aspek perilaku, dapat ditunjukkan dengan menarik diri dari lingkungan sosialnya, nafsu makan berubah drastis (berkurang atau bertambah), dan kualitas tidur terganggu.

Perawat diharuskan mampu mempersiapkan segala sesuatu dengan baik guna keberlangsungan proses keperawatan. Situasi yang tidak kondusif seperti perilaku agresi harus segera diatasi agar tidak berakibat buruk bagi pasien dan perawat itu sendiri, bila situasi yang menekan ini tidak segera diatasi, tidak menutup kemungkinan perawat akan terjebak dalam konflik dan stres yang mana akan mempengaruhi kinerja secara langsung. Berbagai cara dilakukan oleh perawat untuk mengatasi hal ini, agar tidak menimbulkan dampak buruk bagi perawat itu sendiri, salah satunya adalah koping stres. Koping stres amat penting bagi perawat untuk mempertahankan kinerjanya, baik koping stres yang 
berfokus pada penyelesaian masalah maupun koping stres yang berfokus pada emosi diri sendiri. Perawat harus segera melakukan koping stres yang menurutnya paling efektif agar tidak terjebak dalam kondisi stres yang lebih parah. Dengan melalui koping, perawat dapat menunjuk pada berbagai upaya, baik mental maupun perilaku untuk mengatasi, menoleransi, mengurangi, atau meminimalisir suatu situasi atau kejadian yang penuh tekanan. Dengan kata lain kita berusaha untuk menangani dan menguasai situasi stres yang menekan akibat dari masalah yang sedang kita hadapi, dengan cara melakukan perubahan kognitif maupun perilaku guna memperoleh rasa aman secara psikologis (Coyne, Aldwin, \& Lazarus, 1981).

Penelitian stres perawat rumah sakit jiwa terkait faktor koping stress terdapat pada penelitian-penelitian sebelumnya. Studi pada perawat di Australia oleh Healy dan McKay (2000) bahwa terdapat beberapa jenis koping stres yang berkorelasi dengan stres perawat rumah sakit jiwa, yaitu escapeavoidance coping, planful problem solving, seeking social support, dan humor. Penelitian Abdalrahim (2013) pada studi literatur stres perawat rumah sakit jiwa menyebutkan bahwa keadaan stres pasien dapat berakibat buruk pada kesehatan dan fungsi aktivitas harian. koping stres yang dilakukan utamanya ialah strategi berbasis solusi, strategi koping orientasi masalah, dan dukungan sosial. Dukungan sosial terutama dari pihak keluarga merupakan komponen penting dari koping stres perawat. Riset oleh Moghaddam, Piri, dan Ahanjan (2016) menyatakan bahwa stres dikatakan berkorelasi dengan koping stres, di antaranya ialah sikap positif pada kerja, dukungan sosial, dan regulasi diri.

Menurut Lazarus \& Folkman (dalam Smet, 1994), strategi koping adalah suatu proses di mana individu mencoba untuk mengelola jarak yang ada antara tuntutan-tuntutan (baik itu tuntutan yang berasal dari individu maupun tuntutan yang berasal dari lingkungan) dengan sumbersumber daya yang mereka gunakan dalam menghadapi situasi stressfull. Ada banyak metode atau strategi koping yang berbeda, tetapi yang paling umum ada delapan seperti yang dijabarkan oleh Folkman (dalam Fei, 2006), yakni sebagai berikut ini: (1) Koping konfrontatif (confrontative coping), dimana individu berpegang teguh pada pendiriannya dan memperjuangkan apa yang diinginkannya; menggambarkan usaha-usaha agresif untuk mengubah situasi. (2) Mencari dukungan sosial (seeking social support), dimana individu berpaling pada orang lain untuk kenyamanan dan saran mengenai bagaimana mengatasi masalah, menunjuk-kan usaha-usaha individu untuk mencari dukungan. (3) Pemecahan masalah yang terencana (planful problem solving), artinya individu memikirkan suatu rencana tindakan untuk memecahkan situasi, menggambarkan 
usaha-usaha problem-focused yang sengaja untuk mengubah situasi. (4) Kontrol diri (self control), menabahkan hati dan tidak membiarkan perasaan terlihat, menunjukkan usaha-usaha individu untuk mengatur perasaan-perasaan.

Menjauhkan (distancing), menggambarkan usaha-usaha individu untuk melepaskan diri. (6) Penilaian positif (Positive reappraisal), menunjukkan usaha-usaha individu untuk menciptakan arti positif dengan memfokuskan pada pertumbuhan pribadi. (7) Menerima tanggung jawab (accepting responsibility), pengakuan individu bahwa dirinya sendirilah yang mengakibatkan masalah, dan mencoba belajar dari pengalaman. Lebih jelasnya, bentuk koping ini menekankan aspek pengenalan peran diri sendiri dalam suatu masalah. (8) Menghindari penghindaran (escape-avoidance), koping ini terkait dengan wishful thinking dan menunjukkan perilaku-perilaku melarikan diri atau menghindar bisa dengan cara merokok, mengkonsumsi obat-obatan maupun minuman keras, ataupun makan berlebihan.

Perlu digarisbawahi walaupun sebagian besar stresor memunculkan kedua macam strategi koping (problem focused coping dan emotional focused coping), problem focused coping cenderung menonjol ketika seseorang merasakan bahwa sesuatu yang sifatnya konstruktif bisa dilakukan. Sedangkan emotional focused coping cenderung menonjol ketika seseorang merasa bahwa stresor merupakan suatu penderitaan (Carver, Scheier, \& Weintraub, 1989).

Dari uraian di atas, perlu diketahui pemakaian koping pada perawat dalam beradaptasi dengan stres yang dihadapinya, sehingga muncul suatu pertanyaan apakah ada hubungan antara koping stres dan tingkat stres pada perawat yang bekerja pada bagian rawat inap psikiatri rumah sakit jiwa "X".

\section{Metode}

Subjek penelitian terdiri dari total 81 orang perawat yang bertugas pada ruang rawat inap psikiatri. Subjek yang dilibatkan berusia 18-59 tahun. Rentang usia tersebut dipilih karena masih termasuk dalam usia perkembangan dewasa awal yaitu 18-40 tahun dan masa dewasa tengah yaitu 41-60 tahun. Pada usia tersebut, subjek seharusnya sudah memiliki kematangan emosi (Hurlock, 2007).

Skala koping yang digunakan merupakan skala Likert yang terdiri dari lima pernyataan dengan sejumlah pilihan jawaban. Skala Koping Stres dimodifikasi dari Lazarus Coping Scale yang diadaptasi dari Fei (2006). Skala Koping Stres ini menggunakan delapan aspek dari Lazarus. Skala ini terdiri dari 4 pilihan jawaban yang bergerak mulai dari angka 1 yang menandakan tidak pernah hingga angka 4 yang menandakan sangat sering, namun pada penelitian ini dimodifikasi menjadi 5 
pilihan jawaban (skala Likert) untuk mempermudah subjek dalam memberikan respon. Subjek diminta untuk menyatakan dirinya pada lima pilihan jawaban, yakni 1 = tidak pernah, $2=$ jarang, $3=$ normal, $4=$ sering, 5 = sangat sering.

Skala Stres yang digunakan pada penelitian ini disusun sendiri oleh peneliti. Menurut Visides, Eddy, dan Mozie (dalam Rice, 1992), terdapat lima aspek yang digunakan untuk pengukuran dalam skala ini yaitu aspek fisik, aspek emosional, aspek kognitif, dan aspek perilaku. Skala Stres pada perawat memiliki lima alternatif jawaban, yaitu STS (Sangat Tidak Sesuai), TS (Tidak Sesuai), S (Sesuai), dan SS (Sangat Sesuai). Skor penilaian bergerak dari angka satu sampai dengan angka lima.

Data kuantitatif yang diperoleh dianalisis menggunakan teknik analisis korelasi Product Moment dari Pearson dengan bantuan program SPSS for Windows version 20.

Pada uji coba instrumen skala, subjek yang dilibatkan merupakan perawat ruang rawat inap psikiatri $\mathrm{X}$ dan $\mathrm{Y}$ rumah sakit jiwa "X" sejumlah 30 orang dengan hasil pada Skala Koping Stres menunjukkan koefisien reliabilitas sebesar 0,910 sedangkan pada Skala Stres menunjukkan koefisien reliabilitas sebesar 0,905.

\section{Hasil}

Hasil penelitian menunjukkan pada skala koping diperoleh rerata hipotetik 114 dan standar deviasi 91,2. Pada skor empirik memiliki rerata 120,5679 dan standar deviasi sebesar 18,40648. Pada Skala Stres diperoleh rerata hipotetik sebesar 78 dan standar deviasi sebesar 62,4. Pada skor empirik diperoleh rerata 57,2716 dan standar deviasi 13,02691:

Tabel 1. Kategorisasi Variabel Koping Stres

\begin{tabular}{ccc}
\hline Kategorisasi & Frekuensi & Persentase \\
\hline Sangat Rendah & 13 & $16 \%$ \\
Rendah & 8 & $9.9 \%$ \\
Sedang & 25 & $30.9 \%$ \\
Tinggi & 34 & $42 \%$ \\
Sangat Tinggi & 1 & $1.2 \%$ \\
\hline
\end{tabular}

Tabel 2. Kategorisasi Variabel Stres

\begin{tabular}{ccc}
\hline Kategorisasi & Frekuensi & Persentase \\
\hline Sangat Rendah & 2 & $2.5 \%$ \\
Rendah & 21 & $25.9 \%$ \\
Sedang & 36 & $44.4 \%$ \\
Tinggi & 15 & $18.5 \%$ \\
Sangat Tinggi & 7 & $8.6 \%$ \\
\hline
\end{tabular}


Berdasarkan hasil kategorisasi pada tabel di atas, dapat disimpulkan bahwa sebagian besar subjek memiliki kemampuan koping stres pada kategori tinggi (42\%), dan sebagian besar subjek mengalami stres pada tingkat sedang (44.4\%)

Berdasarkan hasil uji normalitas pada subjek menunjukkan bahwa data variabel stres terdistribusi secara normal, yaitu nilai $K S-Z=0,669$ dengan signifikansi $p$ $=0,762(\mathrm{p}>0,05)$. Sementara itu, hasil uji normalitas untuk variabel koping distribusi dinyatakan normal yaitu nilai $\mathrm{KS}-\mathrm{Z}=1,356$ dengan signifikansi $p=0,051(p>0,05)$.

Berdasarkan uji linieritas yang telah dilakukan, maka hasil menunjukkan bahwa antara dimensi problem focused coping dan tingkat stres pada perawat tidak linier, yaitu nilai $F=0,632$ dengan signifikansi $0,430(p$ $>0,05$ ). Pada dimensi lain yaitu dimensi emotional focused coping dan tingkat stres pada perawat tidak linier, yaitu nilai $F=$ $0,052$ dengan signifikansi 0,821 ( $p>0,05)$.

Tabel 3. Hasil Uji Hipotesis

\begin{tabular}{cccc}
\hline Variabel & $\begin{array}{c}\text { Koefisien } \\
\text { Korelasi }(\mathrm{r})\end{array}$ & $\begin{array}{c}\text { Koefisien Signifikansi } \\
(\mathrm{p})\end{array}$ & Keterangan \\
\hline $\begin{array}{c}\text { Problem focused coping } \\
\text { dan stres }\end{array}$ & 0,091 & 0,210 & Tidak Signifikan \\
$\begin{array}{c}\text { Emotional focused } \\
\text { coping dan stres }\end{array}$ & -0.042 & 0,709 & Tidak signifikan \\
\hline
\end{tabular}

Tabel 4. Koefisien Korelasi antara Stres dan Aspek Dimensi Koping Stres

\begin{tabular}{ccccccccc}
\hline & Confrontative & $\begin{array}{c}\text { Social } \\
\text { Support }\end{array}$ & Planfull & $\begin{array}{c}\text { Self } \\
\text { Control }\end{array}$ & Distancing & Reappraisal & Responsibility & $\begin{array}{c}\text { Escape } \\
\text { Avoidance }\end{array}$ \\
\hline Stres & 0,50 & 0,162 & $-0,26$ & 0,093 & 0,199 & $-0,59$ & $-0,128$ & $-0,109$ \\
\hline
\end{tabular}

Hasil analisis data menunjukkan tidak adanya korelasi antara dimensi problem focused coping dan tingkat stres yang ditunjukkan dengan koefisien korelasi $r=0,091, p=0,210(p>0,05)$. Selanjutnya, hasil analisis data juga menunjukkan bahwa tidak adanya korelasi antara dimensi emotional focused coping dan tingkat stres yang ditunjukkan dengan koefisien korelasi $r=-0,042, p=0,709(p>0,05)$. Berdasarkan hasil analisis dapat dilihat bahwa kedua hipotesis yang diajukan tidak diterima.
Uji tambahan dilakukan untuk mengetahui perbedaan tingkat stres antara kedua kelompok subjek, yaitu pada perawat laki-laki dan perempuan. Jumlah subjek lakilaki sebanyak 42 orang (51,86\%), sedangkan perempuan sebanyak 39 orang $(48,14 \%)$. Uji tambahan dilakukan dengan menggunakan teknik Independent Samples T-test. Berdasarkan analisis yang telah dilakukan diperoleh signifikansi $p=0,612(p>0,05)$. Dengan demikian hasil tersebut menunjukkan bahwa tidak terdapat 
perbedaan stres secara signifikan pada perawat laki-laki dan perempuan.

Pada kelompok subjek dengan masa kerja 1-18 tahun dan 19-36 tahun. Jumlah subjek dengan masa kerja 1-18 tahun sebanyak $53(65,43 \%)$ orang, sedangkan subjek dengan masa kerja 19-36 tahun sebanyak 28 orang $(34,57 \%)$. Berdasarkan hasil analisis yang telah dilakukan diperoleh signifikansi $\mathrm{p}=0,880(\mathrm{p}>0,05)$. Dengan demikian, tidak ada perbedaan stres yang signifikan antara subjek dengan masa kerja 1-18 tahun dan subjek dengan masa kerja 19-36 tahun.

Pada kelompok usia, dilakukan uji tambahan antara kelompok subjek berusia 18-40 tahun dan subjek berusia 41-59 tahun. Jumlah subjek berusia 18-40 tahun sebanyak 59 subjek (72,83\%), sedangkan jumlah subjek berusia 41-59 tahun sebanyak 22 subjek (27,17\%). Berdasarkan hasil analisis yang telah dilakukan diperoleh signifikansi $\mathrm{p}=0,419(\mathrm{p}>0,05)$. Dengan demikian, tidak ada perbedaan stres yang signifikan antara subjek berusia 18-40 tahun dan subjek dengan berusia 41-59.

\section{Pembahasan}

Penelitian ini bertujuan untuk menguji hubungan antara koping stres dengan stres pada perawat ruang psikiatri rumah sakit jiwa. Penelitian ini melibatkan 81 subjek yang merupakan perawat yang bertugas di ruang psikiatri rumah sakit jiwa " $\mathrm{X}$ " yang terdiri dari 42 perawat yang berjenis kelamin laki-laki dan 39 perawat yang berjenis kelamin perempuan dengan rentang usia antara 23 hingga 59 tahun.

Berdasarkan hasil analisis data yang telah dilakukan, penelitian ini menunjukkan bahwa tidak terdapat hubungan antara dimensi-dimensi koping stres dengan tingkat stres pada perawat. Pada dimensi problem focused coping arah korelasi positif, namun pada dimensi emotional focused coping arah korelasi negatif, meskipun kedua dimensi tersebut tidak signifikan.

Peneliti terdahulu menyatakan bahwa terdapat korelasi stres dengan dimensi koping. Pada penelitian Ryan (2013) membuktikan bahwa individu yang mempersepsi keadaan dengan stres secara signifikan berkorelasi positif dengan emotional focused coping, namun tidak berkorelasi dengan problem focused coping. Penelitian lainnya yang dilakukan oleh Anam dan Himawan (2005) menyatakan bahwa emotional focused coping secara signifikan berkorelasi negatif dengan keadaan stres. Analisis korelasi antardimensi dan tingkat stres juga telah dilakukan. Sebagaimana penelitian sebelumnya yang dilakukan oleh Hirsch, Barlem, Tomaschewski-Barlem, Lunardi, dan Oliveira (2015) yang menyatakan bahwa terdapat korelasi signifikan antara dimensi koping stres dan stres berupa perencanaan/penyelesaian masalah (planning/problem solving). Sementara dimensi lainnya berupa penilaian positif 
(positive reappraisal), menghindari penghindaran

(escape-avoidance, distancing), menerima tanggung jawab (accepting responsibility), dan mencari dukungan sosial (seeking social support) tidak berkorelasi signifikan.

Koping yang efektif akan menghasilkan adaptasi yang menetap yang merupakan kebiasaan baru dan perbaikan dari situasi lama, sedangkan koping yang tidak efektif berakhir dengan maladaptif yaitu perilaku yang menyimpang dari keinginan normatif dan dapat merugikan diri sendiri maupun orang lain atau lingkungan, setiap individu dalam melakukan koping tidak sendiri dan tidak hanya menggunakan satu strategi tetapi dapat melakukanya bervariasi, hal ini tergantung dari kemampuan dan kondisi individu (Rasmun, 2004).

Menurut Selye (dalam Hawari, 2006), pada fase stres tubuh mencoba berbagai macam mekanisme penanggulangan psikologis dan pemecahan masalah serta mengatur strategi untuk mengatasi stresor. Tubuh berusaha mengimbangi proses fisiologis yang telah dipengaruhi selama reaksi waspada untuk sedapat mungkin kembali pada keadaan normal dan pada waktu yang sama tubuh mengatasi faktor-faktor penyebab stres. Bila teratasi, gejala stres akan menurun tetapi bila tidak, stresor akan berjalan terus dan ketahanan tubuh untuk beradaptasi akan habis karena ketahanan tubuh memiliki batas dalam beradaptasi. Jika stresor berjalan terus dan tidak dapat diatasi/terkontrol maka ketahanan tubuh untuk beradaptasi akan habis dan timbul berbagai keluhan pada individu.

Dalam pelayanan kesehatan, perawat yang mengalami stres berat dapat kehilangan motivasi, mengalami kejenuhan yang berat dan tidak masuk kerja lebih sering. Kegagalan dalam mengurangi dan menghilangkan stresor yang terkait dengan pekerjaan tergantung pada pendekatan yang dilakukan oleh individu tersebut. Dalam hal ini perlu adanya proses adaptasi bagi perawat terhadap adanya stres mengingat dampaknya yang begitu besar dan keberhasilan dalam adaptasi tergantung dari seberapa kuat mekanisme pertahanan jiwa seseorang.

Setiap orang dapat mengalami stres, sebab stres memberi dampak secara total pada individu yaitu terhadap fisik, psikologis, intelektual, sosial dan spiritual. Stres dapat mengancam keseimbangan fisiologis. Stres adalah reaksi tubuh terhadap situasi yang menimbulkan tekanan, perubahan, ketegangan emosi, dan lain-lain yang disebabkan segala masalah atau tuntutan penyesuaian diri, dan karena itu merupakan sesuatu yang mengganggu keseimbangan kita (Maramis, 1999).

Tingkat stres yang dirasakan tiap individu dapat berbeda-beda tergantung bagaimana individu tersebut memaknai 
stresor yang ada dan bagaimana individu tersebut melakukan koping terhadap stres (Ernawati, 2007). Hal tersebut sesuai dengan pendapat Ashby (dalam Prestiana \& Purbandini, 2012) bahwa stres terjadi memang bukan saja karena seseorang memiliki pengalaman yang tidak menyenangkan, gagal dalam berusaha, melainkan juga terjadi karena orang tersebut tidak memiliki sumber daya dan keterampilan yang bisa membantunya memecahkan masalah yang mereka hadapi. Oleh karena itu, agar tidak terjadi hal yang tidak diinginkan yang berhubungan dengan stres pada perawat terutama tentang cara penanggulangan stres itu sendiri, maka perawat harus memahami tentang stres kerja yang bisa muncul sewaktu-waktu saat bekerja.

Berdasarkan hasil analisis tambahan, ditunjukkan bahwa tidak ada perbedaan tingkat stres yang signifikan antara subjek laki-laki dan perempuan dengan $t=0,509(p>0,05)$. Hasil analisis tersebut membuktikan bahwa jenis kelamin tidak mempengaruhi perbedaan tingkat stres secara signifikan. Hal ini berarti jenis kelamin tidak begitu memberikan kontribusi yang besar bagi stres yang dialami. Tingkat stres yang dialami oleh perempuan maupun laki-laki cenderung sama. Jenis kelamin tidak terlalu memberikan pengaruh pada stres bila dibandingkan dengan perbedaan peran maskulin dan feminin yang dirasakan oleh individu, dimana perbedaan peran ini lebih mengacu pada kondisi psikologis sedangkan jenis kelamin lebih mengacu pada kondisi fisiologis. Perbedaan peran mempengaruhi tingkat stres individu yang dirasakan di tempat kerja (Wu \& Shih, 2010).

Uji tambahan juga dilakukan untuk mengetahui pengaruh masa kerja dan usia terhadap stres. Hasil uji independent t-test untuk variabel masa kerja didapatkan nilai $p$ $=0,880(\mathrm{p}>0,05)$, dapat disimpulkan bahwa tidak ada hubungan yang signifikan antara masa kerja dengan stres yang dialami oleh perawat di ruang rawat psikiatri. Hasil uji pada variabel lama kerja berbeda dengan penelitian yang dilakukan oleh Prihatini (2007), bahwa perawat yang bekerja lebih dari 5 tahun telah mampu menyesuaikan diri dengan tempat dimana ia bekerja, hal inilah yang membuat perawat tersebut terbiasa dengan kondisi pekerjaan yang harus dilakukan sehari-hari pada tempat dan waktu yang sama sehingga mereka cenderung tidak mengalami stres daripada perawat yang belum lama bekerja. Hal ini juga sama dengan hasil penelitian dari Rustiana (2008) yang memaparkan bahwa perilaku perawat dalam merawat pasien dipengaruhi oleh masa kerja perawat, hal ini karena semakin lama perawat bekerja maka kemampuan dan pengalaman dalam merawat juga akan semakin baik.

Pada variabel usia perawat, berdasarkan hasil uji independent t-test tampak bahwa usia tidak memiliki 
hubungan dengan stres, dimana nilai $\mathrm{p}=$ $0,419(p>0,05)$. Hal ini tidak sesuai dengan penelitian yang dilakukan oleh Prihatini (2007) yang menyatakan bahwa, perawat yang berusia dewasa mampu mengatasi stres dengan baik sehingga mengurangi dampak dari stres kerja. Hal ini disebabkan, pada usia ini perawat sudah mempunyai fungsi sosial yang baik. Usia sangat berperan penting dalam kematangan seseorang. Pada individu yang usianya lebih tinggi akan cenderung memiliki pemikiran dan keputusan yang lebih bijaksana dan matang dalam menghadapi masalah sehingga dapat mengurangi stres (Ratih \& Suwandi, 2013). Dari pernyataan tersebut dapat dikatakan bahwa usia memiliki hubungan dengan kejadian stres. Hal ini bisa saja terjadi karena faktor yang mempengaruhi stres pada perawat selain kejenuhan dalam bekerja adalah pengalaman seseorang dalam menghadapi suatu pekerjaan dan beban kerja yang dirasakan oleh perawat (Ismafiaty, 2011).

Berdasarkan kategorisasi skor empirik pada variabel koping menunjukkan bahwa sebagian besar subjek berada pada kategori tinggi dengan persentase 42,0\% yaitu sebanyak 34 orang. Hal tersebut menunjukkan bahwa subjek memiliki tingkat koping yang tinggi. Skor koping yang tinggi berarti individu memiliki kemampuan koping yang baik sehingga cukup dapat mengelola stresnya dengan baik.
Berdasarkan kategorisasi dari skor empirik pada variabel stres, dapat dilihat bahwa sebagian besar subjek memiliki tingkat stres yang sedang dengan persentase 44,4\% yaitu sebanyak 36 subjek. Hal tersebut menunjukkan bahwa subjek memiliki tingkat stres pada pekerjaan yang sedang.

Berdasarkan uraian di atas, penelitian ini menunjukkan bahwa sebagian besar perawat $(44,4 \%)$ mengalami stres yang sedang dan sebagian besar perawat $(42,0 \%)$ memiliki skor koping yang tinggi. Kondisi tersebut menggambarkan bahwa kemampuan koping stres yang cukup baik sekalipun tetap dapat mengakibatkan stres pada perawat pada tingkat sedang. Melalui hasil penelitian dan pembahasan, dapat disimpulkan bahwa koping stres tidak dapat menandai tinggi rendahnya tingkat stres yang dialami seseorang.

\section{Simpulan}

Hasil penelitian ini menunjukkan bahwa tidak terdapat korelasi yang signifikan antara dimensi-dimensi koping stres dans stres pada perawat yang bekerja pada bagian rawat inap psikiatri.

\section{Saran}

Bagi penelitian selanjutnya, diharapkan dapat menambah jumlah responden penelitian agar lebih representatif untuk penelitian. 


\section{Daftar Pustaka}

Abdalrahim, A.A. (2013). Stress and coping among psychiatric nurses. Middle East Journal of Nursing, 7,(4), 30 - 37.

Anam, C., \& Himawan, A. T. (2005). Peran emotion-focused coping terhadap kecenderungan post-traumatic stress disorder para karyawan yang menyaksikan peledakan bom di depan kedutaan besar Australia di Jakarta tahun 2004. Humanitas: Jurnal Psikologi Indonesia, 2(2), 112118.

As'ad, M. dan Soetjipto, H.P. (2000). Hubungan antara beberapa aspek budaya perusahaan dengan tingkat burnout pada karyawan bagian pelayanan publik. Jurnal Psikologi, 2, 101- 110.

Azhar (2010). Gambaran stres perawat di unit rawat inap rumah sakit jiwa daerah propinsi Sumatera Utara tahun 2010 (Skripsi). Universitas Sumatera Utara, Medan.

Carver, C. S., Scheier, M. F., \& Weintraub, J. K. (1989). Assessing coping strategies: A theoretically based approach. Journal of Personality and Social Psychology, 56(2), 267-283.

Coyne, J., Aldwin, C., \& Lazarus, R. (1981). Depression and coping in stressfull episodes. Journal of Abnormal Psychology, 50(2), 234-254.

Creswell, J. W. (1998). Qualitative inquiry and research design: Choosing among five traditions. London: Sage Publication.

Elita, V., Setiawan, A., Wahyuni, S., \& Woferst. R. (2011). Persepsi perawat tentang perilaku kekerasan yang dilakukan pasien di ruang rawat inap jiwa. Jurnal Ners Indonesia, 1(2), 31-40.
Ernawati. (2007). Analis faktor yang mempengaruhi mekanisme koping pada mahasiswa USU. Naskah Publikasi. Tidak diterbitkan. Medan : Universitas Sumatera Utara.

Eysenck, M.W. (1993). Priciples of cognitive psychology. United Kingdom: Lawrence Erlbaum Associates, Ltd.

Fei, M. O. (2006). Coping stres pada perawat bagian UGD dan bagian ICU di Rumah Sakit Katholik ST. Vincentius A Paulo Surabaya (Skripsi tidak diterbitkan). Fakultas Psikologi, Universitas Surabaya, Surabaya.

Hasan, A. A. (2017). Work stress, coping strategies, and levels of depression among nurses working in mental health hospital in Port-Said city. International Archieves of Nursing and Health Care, 3(2), 1 - 10.

Hawari D. (2006). Manajemen stres, cemas, depresi (Edisi ke-2). Jakarta: Balai Penerbit FKUI

Healy, C. M., \& McKay, M. F. (2000). Nursing stress: The effects of coping strategies and job satisfaction in a sample of Australian nurses. Journal of Advanced Nursing, 31(3), 681-688.

Hirsch, C. D., Barlem, E. L. D., TomaschewskiBarlem, J. G., Lunardi, V. L., \& Oliveira, A. C. C. D. (2015). Predictors of stress and coping strategies adopted by nursing students. Acta Paul Enferm, 28(3), 224-229.

Humpel, N., \& Caputi, P. (2001). Exploring the relationship between work stress, years of experience, and emotional competency using a sample of Australian mental health nurses. Journal of Psychiatric and Mental Health Nursing, 8, 399-403.

Hurlock, B. E. (2007). Psikologi perkembangan suatu pendekatan sepanjang rentang kehidupan. Jakarta: Erlangga 
Ismafiaty. (2011). Hubungan antara strategi koping dan karakteristik perawat dengan stres kerja di ruang perawatan intensif RS. Dustira Cimahi. Jurnal Kesehatan Kartika, 9, 38-53.

Kusumawati, A. (2008). Stres dan koping perawat pada penanganan pasien perilaku kekerasan di instalasi rawat inap RSJD Dr. Amino Gondohutomo Semarang. (Skripsi). Fakultas Kedokteran, Universitas Diponegoro, Semarang.

Kozier, B. (2004). Fundamentals of nursing. New Jersey: Pearson Education.

Lazarus, R.S., \& Folkman, S. (1984). Stress, appraisal, and coping. New York: Springer Publishing Company

Mangoulia, P., Koukia, E., Alevizopoulos, G., Fildissis, G., \& Katostaras, T. (2015). Prevalence of secondary traumatic stress among psychiatric nurses in Greece. Archives of Psychiatric Nursing, 29(5), 333-338.

Maria, M., Pavlos, S., Eleni, M., \& Thamme, K. (2010). Greek registred nurses' job satisfaction in relation to work related stress: A study on army and civilian Rns. Global Journal of Health Science, 2(1), 44-59.

Maramis W.F. (1999). Catatan ilmu kedokteran jiwa. Surabaya: Airlangga University Press

Moghaddam, Y. V., Piri, S., \& Ahanjan, P. (2016). Stressors and coping strategies of psychiatric nurses in razi medical center of Tabriz city. International Journal of Pharmaceutical Research and Allied Sciences, 5(2), 451-456.

Prestiana, N., D. \& Purbandini, D. (2012). Hubungan antara efikasi diri dan stres kerja dengan kejenuhan kerja pada perawat IGD dan ICU RSUD Kota Bekasi. Jurnal Soul, 5(2), 32-45.
Prihatini, L. D. (2007). Analisis hubungan beban kerja dengan stres kerja di ruang rawat inap RSUD Sidikalan. (Skripsi tidak diterbitkan). Universitas Sumatera Utara, Medan.

Rasmun, (2004). Stres, koping, dan adaptasi. Jakarta : Sagung Seto.

Ratih, Y. \& Suwandi, T. (2013). Analisis hubungan antara faktor individu dan beban kerja fisik dengan stres kerja di bagian produksi PT. X Surabaya. The Indonesian Journal of Occupational Safety and Health, 2(2), 97-105.

Ratri, M. S., \& Parmitasari, D. L. (2014). Coping stress pada beban kerja perawat ruang unit pelayanan intensive psikiatri (UPIP) dan ruang kresna di RSJD. Dr. Amino Gondohutomo Semarang. (Naskah Publikasi). Fakultas Psikologi, Universitas Katholik Soegijapranata, Semarang.

Rice, Phillip L. (1992). Stress and health. Second edition. California: Wadsworth, Inc.

Rustiana, E.R. (2008). Stres kerja dan burnout. Jurnal Kesehatan Masyarakat, 4(1), 32-47.

Ryan, K. (2013). How problem focused and emotion focused coping affects college students' perceived stress and life satisfaction. (Bachelor of Arts Thesis). DBS School of Arts, Dublin.

Sarafino, E.P. (1994), Health psychology (2 ${ }^{\text {nd }}$ Ed.). New York: Wiley

Smet, B. (1994). Psikologi kesehatan. Jakarta: Gramedia Widiasarana

Wang, S. M., Lai, C. Y., Chang, Y. Y., Huang, C. Y., Zauszniewski, J. A., \& Yu, C. Y. (2015). The relationships among work stress, resourcefulness, and depression level in psychiatric nurses. Archives of Psychiatric Nursing, 29(1), 64-70. 
Wijono. (2006). Pengaruh kepribadian type A dan peran terhadap stres kerja perawat. Jurnal Kesehatan Insan, $8(3), 23-32$.

Wu, Y., \& Shih, K. (2010). The effects of gender role on perceived job stress, Journal of Human Resource and Adult Learning, 6(2), 43-57. 
